\section{Official controls according to Integrated Regional Plan in Campania Region 2011/2014}

Diletta Mandato, ${ }^{1}$ Germana Colarusso, ${ }^{1}$ Roberta Pellicanò, ${ }^{1}$ Loredana Baldi, ${ }^{1}$ Achille Guarino, ${ }^{1}$ Paolo Sarnelli ${ }^{2}$

${ }^{1}$ Institute for Experimental Veterinary Medicine of Southern Italy, Portici (NA); ${ }^{2}$ Campania Region, Naples, Italy

\begin{abstract}
Due to EU law, European citizens enjoy one of the highest worldwide food safety standards. Along the entire food supply chain, mandatory controls are made to ensure that plant and animal products healthiness and food and feed safety are properly labeled and comply with the strictly EU rules. The process of review of European legislation began with the promulgation of the Regulation 178/2002/EC (Official Journal of the EC no. L31 of $01 / 02 / 2002$ ) and was completed with the hygiene package. Regulation No. 178/2002/EC (the General Food Law) laying down the general principles and requirements of food law, establishing the European Food Safety Authority and laying down procedures in matters of food safety.
\end{abstract}

\section{Introduction}

Due to EU law, European citizens enjoy one of the highest worldwide food safety standards. Along the entire food supply chain, mandatory controls are made to ensure the plants and animals products healthiness and food and feed safety, that are properly labeled and comply with the strictly EU rules.

The process of review of European legislation began with the promulgation of the Regulation 178/2002/EC (Official Journal of the EC no. L31 of 01/02/2002; European Commission, 2002) and was completed with the hygiene package.

Regulation No. 178/2002/EC (the General Food Law) laying down the general principles and requirements of food law, establishing the European Food Safety Authority and laying down procedures in matters of food safety.

The hygiene package, initially consisting of four regulations - two related to the food production and marketing (Reg. 852/04 and Reg. 853/04/EC; European
Commission, 2004a, 2004b) and two on the competent authorities modality controls by the (Reg. 854/04/EC and Reg. 882/04/EC; European Commission, 2004c, 2004d) - it was later integrated to ensure a higher level of the food chain health and hygiene assurance with the EC Regulation 183/2005 laying down the requirements for feed hygiene (European Commission, 2005a), and Regulations 2073/2005/EC, 2074/2005/EC, $2075 / 2005 /$ EC and 2076/2005/EC of 5 December 2005 (European Commission, 2005b, 2005c, 2005d, 2005e) on microbiological criteria, control organizations and transitional measures.

The entry into force of the European regulations in the food safety field is a cultural revolution in official controls relating to food, feed and health and animal welfare, both in relation to the legislative radical change, previously formed by a large number of vertical standards, both for the large space reserved for some basic concepts, such as the risk assessment based controls planning to rationalize and optimize the available resources. The risk assessment is the reference tool to identify a country health priorities; it must be linked to the choices of some basic parameters for the decisions taken to make food control efficient and effective. On risk assessment, in fact, some European countries, defining the acceptable levels of certain food diseases and, consequently, the acceptable levels of contamination for certain foodstuffs specific hazards.

The official controls implementation are carried out by Competent Authority (CA), which in Italy is identified with the National Health Service in its three joints (Legislative Decree 193/2007, Art. 2): Central (Ministry of Health), Regional (Departments of Health) and territorial (Veterinary Services and the Local Health Authorities SIAN).

In the NHS, the health planning functions, including those relating to the prevention and food safety, are shared between state and regions and with the Entente no. 133/CSR of 14 June 2007, the Standing Conference for relations between the State and Regions outlined the principles for the National Integrated Plan (MANCP) implementation.

The EU Regulation 882/2004, Art. 41 provides that each Member State should develop a single Control National Multiyear integrated plan, on the food safety official controls implementation, intended to verify compliance with hygiene and health food, animal feed, welfare and animal health and plants health EU Regulations Reference. These plans should be prepared in accordance with the art. 42 and 43
Correspondence: Diletta Mandato, Institute for Experimental Veterinary Medicine of Southern Italy, Portici (NA), Italy.

E-mail: diletta.mandato@izsmportici.it

Key words: Food safety; Risk assessment; Risk analysis.

Conflict of interest: the authors declare no potential conflict of interest.

Received for publication: 21 December 2017. Revision received: 28 August 2017.

Accepted for publication: 28 August 2017.

This work is licensed under a Creative Commons Attribution-NonCommercial 4.0 International License (CC BY-NC 4.0).

CCopyright D. Mandato et al., 2017 Licensee PAGEPress, Italy

Italian Journal of Food Safety 2017; 6:5708 doi:10.4081/ijfs.2017.5708

Regulation no. 882/2004 criteria, supplemented by the Commission Decision n. 363 of 21 May 2007.

MANCP goal ensure a high level of consumer health by reducing biological, chemical and physical incidence, promote animal health by preventing/reducing the animal diseases incidence, improve economic growth/ cohesion/competitiveness by ensuring the goods free movement, promote animal welfare farming practices to prevent hazards animal health related, minimize environmental impacts to support the sustainable development EU strategy.

The PRI (Regional Integrated Plan) It is the Campania Region basic instrument intended to use in order that, both at regional and territorial, official controls are planned in accordance with integration and optimization principles for the Community instructions implementation in accordance with the respectively State and Regions conferred powers.

PRI describes the involved people and activities, how compliance with the required standards it is ensured and review and updating measures about food safety, animal health and welfare and plants health official controls, and the related information flows.

\section{Materials and Methods}

In Campania Region activities related to food safety and animal health are managed and recorded by a regional web platform, called GISA. This is used by the CA to insert all relevant companies information: risk-based categorization, official control 
activities and nonconformities.

From 2015 considering the provisions Law 116/14 regarding farms and DGRC $623 / 14$ on administrative offenses, it will be also used by other Authorities such as Police Forces.

GISA, accessible from the Regional Observatory for Food Safety (ORSA, 2017) website, allows: i) all Campania establishments/companies records consultation inherent to food safety and veterinary public health; ii) identified dogs and their owners records (known as the Regional Data Bank - BDR); iii) monitoring of the operational targets and other planned activities implementation; iv) evaluate the PRI suitability to deal with the food safety, veterinary public health and plant health issues.

GISA is designed for the data exchange with other informatics systems by application cooperation mode. A Region goal is to implement this mode more and more to apply the simplification, dematerialization rules and PA efficiency respecting the principle of loyal cooperation enshrined in article 22 institutional c.5 law n. 241/90.

GISA allows establishments and noncompliance georeferencing according to selected parameters. It is also equipped with a specific software intended to reporting, so as to obtain a real time data aggregation to improve the regional controls whole system efficiency. The system is accessible only to official control operators who are assigned a username and password. Access, as mentioned, is also allowed to the other Authorities who carry out complementary food safety, veterinary public health and plants health, so they can enter their inspections details. This allows all control bodies to see companies records, the carried out controls and all other relevant information.

\section{Results and Discussion}

In 2011-2014, 294.557 Official Controls were carried out and recorded. The most of checks is carried out on registered and approved establishments and on farms. The official controls are represented by $91 \%$ (270.124) by simple inspection, $8 \%$ of inspections for the risk categorization of the establishments (22.463) and $0.6 \%$ by the audits (1617); the remaining $0.4 \%$ are inspections carried out for other reasons (Figure 1). In this quadrennium were found 22.926 nonconformities in whole region, detected by 15.565 official controls at 10.563 activities. The nonconformities detection is about $99.9 \%$ during simple inspections and only $0.1 \%$ during inspections carried out for establishments' categorization.

The devices (computers, the Internet, databases, computer files, etc.) to carry out the office work and for the network access results better than previous years although several critical remain in peripherals.

Thanks to a general strengthening of cooperation and collaboration (Art. 4, paragraph 3, Regulation (EC) n. 882/2004), the official controls regional program led to a peripheral increasing activities and obligations. The audit showed a Local Health Authorities annual growth thanks to an increase of coordination activities (activation of joint working groups, meetings, technical meetings, etc.).

In general it is registered, compared with a consolidated regional system, an increase in instructions or internal operating procedures production at peripheral level. This increase, however, is still not sufficient to ensure the staff conduct uniformity.

The regional authorities, acting on the

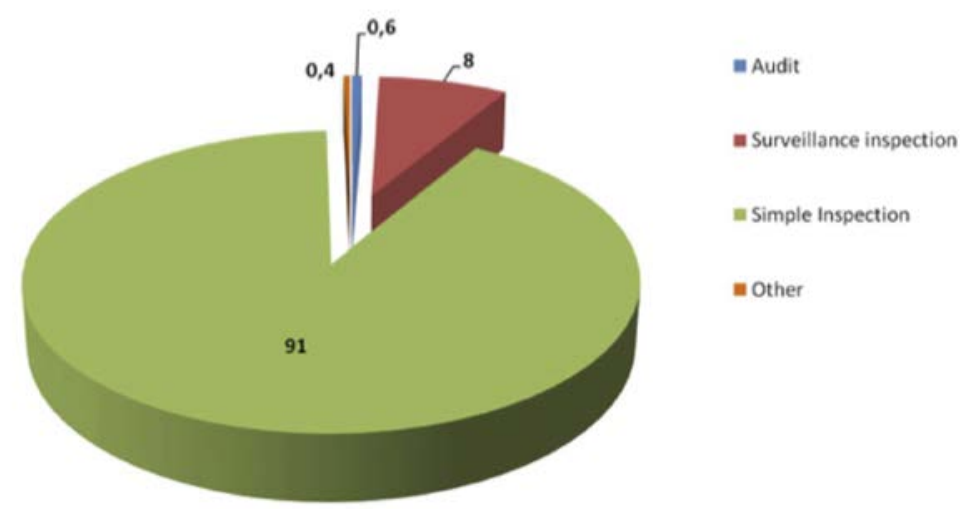

Figure 1. Type of official controls (values are expressed as percentage). ministerial national guidelines recommendations for the Regulations 882-854/2004, drew up and adopted starting from PNI, a multi-year Official controls Regional Plan, whose task is the manage of Community rules obligations and national legislation in the field of veterinary public health and food safety.

Regional planning, generally, has seen the involvement of other agencies or institutional bodies (eg. IIZZSS, ARPA, etc.). The program of official controls in Local Health Authorities was regular and in accordance with the instructions given at the regional level.

During the audit it was verified that the $\mathrm{CA}$ using the main national and regional web database for the official control collection, organization and data reporting.

The CA internal audits activities at FBO-level compared to previous years were satisfactory and increased.

Otherwise it was found diffusely growing inattention on targeted training addressed to health professionals related with food safety and veterinary public health matters. In fact, in $58 \%$ of the audits carried out in 2014, it was reported lack of theoretical/practical training initiatives in audited area.

\section{Conclusions}

During the examined four years, a gradual increase has been noticed in GISA use, both in recording, both in control and sampling activities registered. The most critical master data is borne by the feed business operators and veterinary medicinal products wholesalers. A significant decrease in the risk category in almost half of approved establishments was noticed, while for registered establishments this share amounted to $39 \%$ of the total. For the latter, it should be also noted that, compared to the number of units present in the region, controls are distributed only on a small percentage. There is particularly critical in the wholesale distribution, transportation, and public catering; oppositely there is a constant monitoring on the catering and on other activities. For approved establishments control is more uniform and constant ensuring an annual regular monitoring of all active establishments in Campania region.

\section{References}

European Commission, 2002. Commission Regulation of the European Parliament and of the Council 
of 28 January 2002 laying down the general principles and requirements of food law, establishing the European Food Safety Authority and laying down procedures in matters of food safety, 178/2002/EC. In: Official Journal, L 31, 1.2.2002.

European Commission, 2004a. Commission Regulation of the European Parliament and of the Council of 29 April 2004 on the hygiene of foodstuffs, 852/2004/EC. In: Official Journal, L 139/1, 30.4.2004.

European Commission, 2004b. Commission Regulation of the European Parliament and of the Council of 29 April 2004 laying down specific hygiene rules for food of animal origin, $853 / 2004 /$ EC. In: Official Journal, L 139, 30.4.2004.

European Commission, 2004c. Commission Regulation of the European Parliament and of the Council of 29 April 2004 laying down specific rules for the organization of official controls on products of animal origin intended for human consumption,
854/2004/EC. In: Official Journal, L 139, 30.4.2004.

European Commission, 2004d. Commission Regulation of the European Parliament and of the Council of 29 April 2004 on official controls performed to ensure the verification of compliance with feed and food law, animal health and animal welfare rules, $882 / 2004 /$ EC. In: Official Journal, L 191, 28/05/2004.

European Commission, 2005a. Commission Regulation of the European Parliament and of the Council of 12 January 2005 laying down requirements for feed hygiene, 183/2005/CE. In: Official Journal, L 35/1, 8.2.2005.

European Commission, 2005b. Commission Regulation of 15 November 2005 on microbiological criteria for foodstuffs, 2073/2005/EC. In: Official Journal, L 338/1, 22.12.2005.

European Commission, 2005c. Commission Regulation of 5 December 2005 laying down implementing measures for certain products under
Regulation (EC) No 853/2004 of the European Parliament and of the Council and for the organisation of official controls under Regulation (EC) No 854/2004 of the European Parliament and of the Council and Regulation (EC) No $882 / 2004$ of the European Parliament and of the Council, derogating from Regulation (EC) No 852/2004 of the European Parliament and of the Council and amending Regulations (EC) No 853/2004 and (EC) No 854/2004, 2074/2005/EC. In: Official Journal, L 338/27, 22.12.2005.

European Commission, 2005d. Commission Regulation of 5 December 2005 laying down specific rules on official controls for Trichinella in meat, 2075/2005/EC. In: Official Journal, L 338/60, 22.12.2005.

European Commission, 2005e. Commission Regulation laying down transitional arrangements for the implementation of Regulations (EC) No. 853/2004, (EC) No. 854/2004, 2076/2005/EC. In: Official Journal, L $338 / 83,22.12 .2005$. 